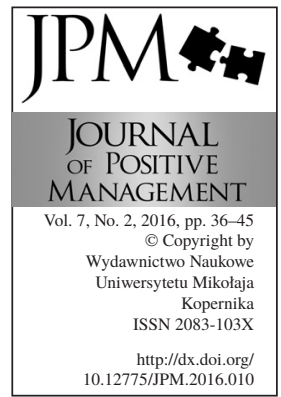

\title{
ANALYSIS OF THE IMPACT OF STANDARDIZED QUALITY MANAGEMENT SYSTEM FOR THE IMPROVEMENT OF COOPERATION IN THE SUPPLY CHAIN ON THE BASIS OF SMALL AND MEDIUM-SIZED ORGANIZATIONS
}

\author{
Dominik Zimon \\ Rzeszow University of Technology, Rzeszow, Poland \\ e-mail: zdomin@prz.edu.pl
}

\begin{abstract}
Purpose: The main objective of this publication was to investigate the influence of standardized quality management system according to ISO 9001 on the improvement of cooperation in the supply chain from the point of view of small and medium-sized organizations.

Design/methodology/approach: The study was conducted in March and April 2014 using a technique online survey. Surveys were sent to a group of 150 small and medium-sized organizations carrying out their activities in the southern Polish. For the analysis classified 30 correctly completed questionnaires survey. In the study group there were 12 small and 18 medium-sized organizations.

Findings: Analysis of the results showed for positive relationships between the implementation of ISO 9001 and integration with suppliers. In addition, respondents highly evaluated the impact of a standardized system for the improvement of procedures to support collaboration with suppliers.
\end{abstract}

Research limitations/implications: Research for take into account only a narrow aspect of the functioning of the system. Decision on implementation should take into account a number of studies relating to: the effect of ISO on the financial results, the workload for system maintenance, the costs of audits and actions perfected etc.

Practical implications: Test results may be helpful in deciding whether to implement a quality management system in small and medium-sized organizations.

Originality/value: In Polish literature there is still relatively little research on the impact of quality management systems for the betterment of logistics processes.

Keywords: ISO 9001, SMEs, supply chain, cooperation

Paper type: Research paper 


\section{Introduction}

As is well known small and medium-sized enterprises play a key role in the development of the economy. However, their effective and efficient functioning depends on the extent to which they can deal with the obstacles encountered by in their business. The management of small and medium-sized organizations struggling every day with many challenges and obstacles to the smooth functioning of the organization. These barriers are rooted both in the same conditions of the system, as well as the specifics of small and medium-sized organizations. Generally speaking, to system conditions we can include the institutional constraints and regulations (Santos et al., 2013). Whereas technological limitations, lack of innovative solutions, low efficiency of internal processes within the organization and a lack of professional knowledge are the main shortcomings resulting from the nature of small and medium-sized organizations.

Noting the above considerations it can be assumed that small and mediumsized organizations are looking for approaches to ensure that their position in the supply chain could be improved. According to the author implementation of standardized quality management systems in this context it seems to be a good solution. Standardized systems concentrate on the development and maintenance of a stable system of governance for effective implementation, repeatability, minimizing errors, improving key processes and meet the requirements of external stakeholders and clients (Lewis et al., 2006; Haffer, 2010).

It is worth noting that from the point of view of small and medium-sized organizations strengthen relationships in the supply chain seems to be especially important because (Zimon and Gazda, 2015):

1) Smaller organizations (which often serve as an auxiliary in the supply chain), in order to strengthen its position in the market should aspire to the title of stable links in the supply chain, which they're co-create. Road leading to this is a strong integration with other cells and active involvement in the implementation of the strategy outlined by the coordinating link.

2) Cooperation and the pursuit of sustainable partnerships usually results in an increase in the potential of all links in the supply chain, which is extremely important for smaller organizations.

3) Proper operation of the subsystem of supply is crucial for proper implementation of the activities assigned to another subsystems logistics and the same quality of finished products. The main reason for this state of affairs is the fact that supply subsystem is the first subsystem of logistics, closely linked to the subsequent (especially subsystem of production). In addition, as rightly observed by Psomas and coauthors (2011) procurement process connects the supply chain and provides the desired quality created by suppliers in the chain. Quality of service and of property "imcoming"
ANALYSIS

OF THE IMPACT

OF STANDARDIZED

Dominik Zimon 
ANALYSIS

OF THE IMPACT

OF STANDARDIZED

Dominik Zimon to the system affects the quality of the "outgoing" with his products, and thus to customer satisfaction and income of the company.

4) Proper management of relationships with suppliers can significantly result as a minimization of the supply costs, which depending on the specifics of the company and implemented strategy can be up to several tens of percent of total business spending.

5) Suppliers are a source not only of supply products, but also innovation and should be treated as an integral part of the enterprise buyer.

6) Durable integration in the supply chain leads to raising the technological suppliers. Manufacturing companies (acting in their own interest) relatively often decide to transfer knowledge and technology, which may be a significant boost with the development of smaller organizations, which have a limited budget for development.

7) Integration over the long term leads to a blurring of the boundary between the individual links in the supply chain, which favors the implementation of the joint strategy and affects the growth of competitiveness of all its cells.

An analysis of presented reasons shows that proper implementation of the basic processes in the supply chain is increasingly dependent on the cooperation of its individual cells. Frequently practiced range of supply chain management is the integration the company with suppliers the first order. This is the first important step in the integration of all supply chain. According to B. Ocickiej (2013) the process of creating and developing relationships with suppliers should be cocreated by employees representing various business functions in the enterprise and must be focused on improving the value delivered clients and external stakeholders. Analogously to the process of customer relationship management as it relates primarily to the formation of partnerships with suppliers (Kadłubek and Grabara, 2015), providing the highest value in the supply chain, and for relations with traditional transactional nature of the other contractors. The author also stresses that from the point of view of the development of the supply chain the most beneficial form of cooperation with suppliers long-term cooperation is a "win-win".

Taking into account the above considerations, the main aim of this publication is to examine the impact of the implementation of the requirements of ISO 9001 for the improvement of cooperation in the supply chain and of the opinions of top management on ISO 9001. The research will be small and medium-sized organizations because it is believed that ISO 9001 is not taken full account of their specificities, which consists of the following elements (Poksinska et al., 2006; Ghobadian and Gallear, 1996; Zimon, 2015):

- flat organizational structure,

- lack of specialists who could actively participate in the process of improvement of the system, 
- low level of formalization of enterprise management system, and also lacks unequivocal definition of competence, responsibility and the division of tasks,

- restricted equity and the resulting lower self-financing development projects and out loans,

- limited personnel,

- lack of infrastructure needed to meet key customer requirements,

- low involvement of top management in the improvement of the system,

- lack of clearly defined strategy of the system,

- intermingling of different fields and functions in the organization,

- only a partial understanding of the idea of the process approach,

- develop too extensive documentation of system,

- inaccurate scope of responsibilities of employees.

\section{Methodology of the research}

The main objective of this publication was to examine the influence of standardized quality management system according to ISO 9001 on the improvement of cooperation in the supply chain from the point of view of small and mediumsized organizations.

The study was conducted in March and April 2014 using a technique online survey. Surveys were sent to a group of 150 small and medium-sized organizations carrying out their activities in the southern Polish. For the analysis classified 30 correctly completed questionnaires survey. In the study group there were 12 small and 18 medium-sized organizations. The research tool was a questionnaire, which consisted of 15 questions, both open and closed and it is addressed to representatives of the board of the organizations. The paper assumes the following research hypothesis:

- It is assumed that the implementation of standardized quality management system forces the development of standards and procedures that facilitate the integration of suppliers in the supply chain;

- It is assumed that the main premise for the implementation and maintenance of standardized quality management systems in the surveyed organizations is pressure from the key links in the supply chain.

\section{Analysis of the results of research}

First of all the author's intention was to establish the key conditions governing the implementation of system requirements in small and medium-sized organizations. The distribution of responses shown in Figure 1.

Taking into account the considerations made in the introduction to this paper it was assumed that smaller organizations mainly decide to implement the system under pressure from external stakeholders. Analysis of the data shown in Figure 
ANALYSIS

OF THE IMPACT

OF STANDARDIZED

Dominik Zimon

Figure 1.

Themes implementation of the quality management system

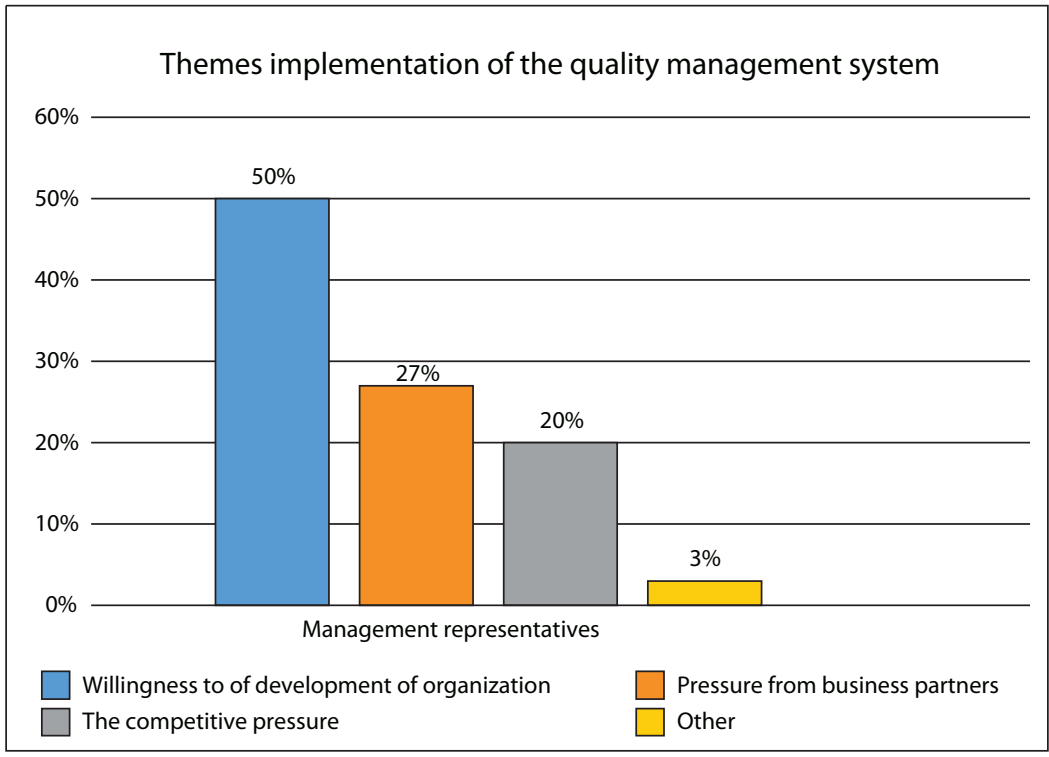

1 does not allow us to accept this thesis. The distribution of responses shows that exactly half of the respondents organization decides to implement a quality management system based on the analysis of their needs, desires and aspirations. Executives from the group argued that the certified system makes it easy to build relationships in the supply chain to better understand the idea of pro-quality approach and to achieve the objectives adopted in the quality policy. The relatively large number of indications for this variant of the responses to the conclusion that quality management systems are properly implemented, and the decision to implement was priming thought, and not taken at the spur of the moment.

Quite a large group (27\%) were the organizations that have decided to implement the system under pressure from the business partners. Respondents in this group emphasized that the standardized quality management system introduces a number of positive changes, but the workload and financial resources for its implementation and improvement discouraged to take independent decisions about its implementation. However, pressure from the business partners were intense enough to decide to implement the system.

Further analysis of the distribution of responses shows that every fifth organization by implementing a standardized quality management system had to improve its competitive position. The premise that could be considered questionable because in the literature one can find studies suggesting that the standard ISO 9001 in small and medium-sized organizations works (Quazi and Padibjo, 1998; Fotopoulos et al., 2010) and those in which the authors suggest that 
a standardized quality management system should not necessarily be implemented in smaller organizations (Gustafsson et al., 2001; Okay and Semiz, 2013; Murmura et al., 2016).

Another question was of a rather general. Respondents in it were asked to express their opinion about the impact of standardized quality management system to improve collaboration with suppliers and initiating integration activities (Figure 2).

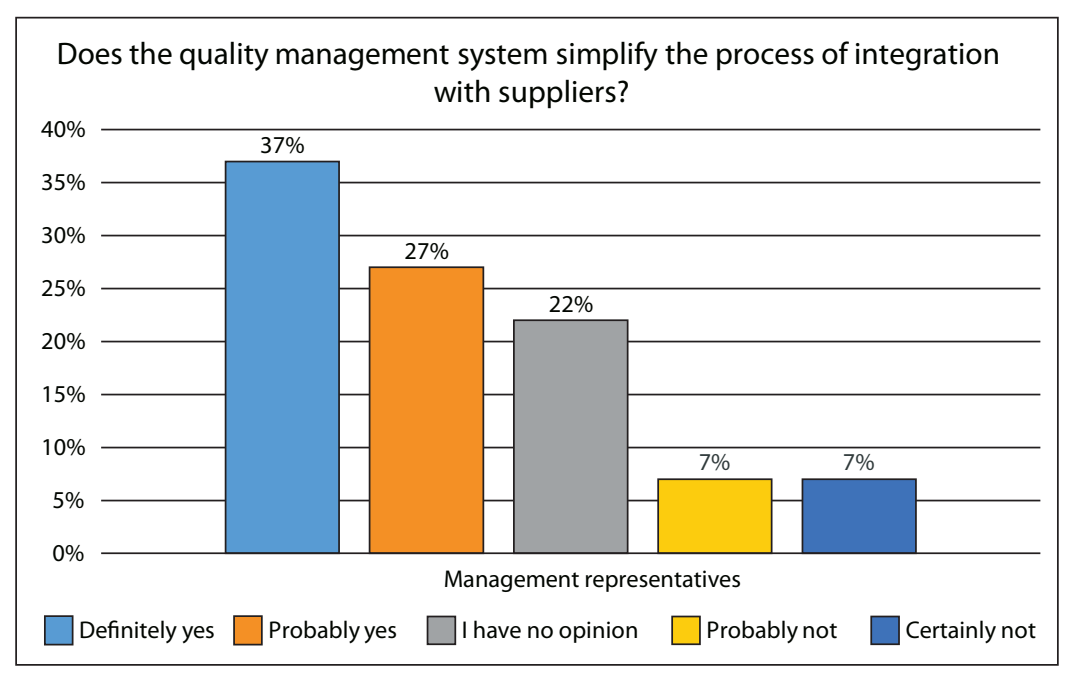

The distribution of responses seems to be beneficial for the supporters of the idea of implementing the requirements of the ISO 9001 in this context. Almost $65 \%$ of respondents stated that the standardized quality management system streamlines the process of integration with suppliers. The obtained result can be explained by the fact that ISO 9001 contains a number of significant requirements for the organization of co-operation, control and choice of suppliers. The distribution of responses shows that compliance with these requirements are suited in the business practice. Quite similar results are presented in their work Magd and Curry (2003).

Noteworthy is quite a large number of respondents $(22 \%)$, which could not clearly answer this question. As rightly observes R. Wolniak (2014), it can result from the fact that the benefits of implementing the system did not materialize immediately. Some delay in the time and complexity of the phenomena causes that do not always appear to be associated with the implemented quality management system.
Figure 2.

Does the quality management system simplify the process of integration with suppliers? 
ANALYSIS

OF THE IMPACT

OF STANDARDIZED

Dominik Zimon

Figure 3.

The impact of the requirements of ISO 9001 to improve various aspects of cooperation with suppliers
A relatively small number of respondents do not notice the positive relationship between the implementation of the system requirements and closer cooperation with suppliers. Bearing in mind the fairly low percentage of negative indications it can be assumed that these organizations may be inadequately developed system procedures in this area. It is believed that the change and adjustment in the long run contribute to the improvement of cooperation with suppliers.

The aim of the last questions was a assess the impact of the requirements of ISO 9001 to improve various aspects of cooperation with suppliers (Figure 3).

The impact of the requirements of ISO 9001 to improve various aspects of cooperation with suppliers

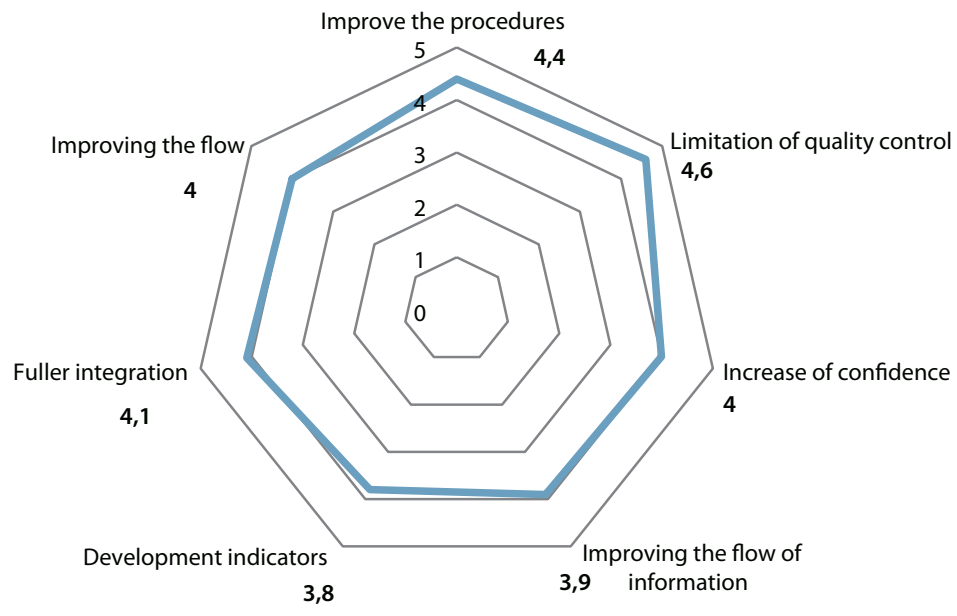

Even a cursory analysis of the distribution of responses shows that ISO 9001 has a significant impact on the improvement of the extracted processes (assessment of individual factors ranged from 3.8 to 4.6 in a 5-point scale). For the top-rated aspects of the respondents passed:

- Limitation of quality control: having systems by the suppliers and customers leads to the adoption of specific standards, the observance of which affects the minimization of errors and mistakes, which translates into less restrictive conducted inspections.

- Improve the procedures: implementing the requirements of the system requires the development of deliberate procedures, taking into account important factors in co-operation with suppliers, making it easier to establish and maintain cooperation. 
- Fuller integration: resulting from the adoption of similar objectives and mutual support during audits.

The other aspects were rated oscillating between 4.0. This allows to say that the small and medium-sized organizations significantly gained through the implementation of system requirements. The results obtained research are quite similar to the results presented in the works of authors such as, among others (Gotzamani et al., 2007; Sousa-Poza et al., 2009).

The lowest result was achieved by factors associated with the development of indicators. According to the author It may result from the general problem of how to the small and medium-sized organizations have with the area of monitoring and measurement projects implemented.

\section{Conclusions}

Conducted research process allowed to respond to the accepted research hypotheses. The first one, in which it was claimed that the implementation of standardized quality management system forces the development of standards and procedures that facilitate the integration of suppliers in the supply chain can be regarded as true. Analysis of the results showed for positive relationships between the implementation of ISO 9001 and integration with suppliers. In addition, respondents highly evaluated the impact of a standardized system for the improvement of procedures to support collaboration with suppliers.

The second hypothesis assuming that the main prerequisite for the implementation and maintenance of standardized quality management systems in the surveyed organizations is pressure from the key links in the supply chain, not proved to be true. Research shows that small and medium-sized organizations in most cases, take the decision to implement the system based on the analysis of their needs. It is worth noting that the conscious implementation of the system in most cases could have a positive impact on the image of the ISO 9001 presented in this report.

Based on the research process was also found that the:

- almost $65 \%$ of the respondents have observed that the implementation of standardized quality management system has a positive effect on the process of cooperation and integration with suppliers,

- organizations that did not notice the positive relations between the ISO 9001 and the improvement of relations with suppliers belonged to a small minority (14\%),

- implementation of ISO 9001 has a positive impact on the improvement of most aspects related to the tightening of relations with suppliers.

In conclusion it should be emphasized that the relatively positive picture of the implementation of the system requirements for smaller organizations, which is apparent from the research, it should not be the only prerequisite for 
ANALYSIS

OF THE IMPACT

OF STANDARDIZED

Dominik Zimon a decision to implement the system. Research for take into account only a narrow aspect of the functioning of the system. Decision on implementation should take into account a number of studies relating to: the effect of ISO on the financial results, the workload for system maintenance, the costs of audits and actions perfected etc. It should be noted also that the introduction of a formalized quality management system compliant with ISO 9001 may limit the flexibility of small and medium-sized organizations, which determines their competitiveness. Most small organizations have serious difficulties in understanding and applying the requirements of ISO 9001, and in particular the need for continuous improvement. In addition, the implementation of quality management system in small and medium-sized organizations tremendous burden and challenge of investment often forcing the total reconstruction of the existing management system (Aggelogiannopoulos et al., 2007). Having regard to the test results and the above suggestions can be stated that the implementation of the system requirements affects the improvement of processes in the supply chain, however, the decision to implement ISO 9001, especially in smaller organizations should always be preceded by a careful analysis of the potential cost and benefits.

\section{References}

Aggelogiannopoulos, D., Drosinos, E. H., Athanasopoulos, P. (2007), "Implementation of a quality management system (QMS) according to the ISO 9000 family in a Greek small-sized winery: A case study", Food control, Vol. 18 No. 9, pp. 1077-1085. DOI: http://dx.doi.org/10.1016/j.foodcont.2006.07.010

Fotopoulos, C. V., Psomas, E. L., Vouzas, F. K. (2010), “ISO 9001: 2000 implementation in the Greek food sector", The TQM Journal, Vol. 22 No. 2, pp. 129-142. DOI: http:// dx.doi.org/10.1108/17542731011024255

Ghobadian, A., Gallear, D. N. (1996), "Total quality management in SMEs", Omega, Vol. 24 No. 1, pp. 83-106. DOI: http://dx.doi.org/10.1016/0305-0483(95)00055-0

Gotzamani, K. D., Tsiotras, G. D., Nicolaou, M., Nicolaides, A., Hadjiadamou, V. (2007), "The contribution to excellence of ISO 9001: the case of certified organisations in Cyprus", The TQM Magazine, Vol. 19 No. 5, pp. 388-402. DOI: http://dx.doi. org/10.1108/09544780710817838

Gustafsson, R., Klefsjö, B., Berggren, E., Granfors-Wellemets, U. (2001), "Experiences from implementing ISO 9000 in small enterprises-a study of Swedish organisations", The TQM Magazine, Vol. 13 No. 4, pp. 232-246. DOI: http://dx.doi. org/10.1108/09544780110366088

Haffer, R. (2010), "Towards business excellence. The case of Poland", Journal of Positive Management, Vol. 1 No. 1, pp. 97-109. DOI: http://dx.doi.org/10.12775/ JPM.2010.008

Kadłubek, M., Grabara, J. (2015), “Customers’ expectations and experiences within chosen aspects of logistic customer service quality", International Journal for Quality Research, Vol. 9 No. 2, pp. 256-278. 
criteria of TQM in ISO 9001 certified small and medium-sized enterprises", International Journal of Quality \& Reliability Management, Vol. 23 No. 8, pp. 964-985. DOI: http://dx.doi.org/10.1108/02656710610688167

Magd, H., Curry, A. (2003), "An empirical analysis of management attitudes towards ISO 9001: 2000 in Egypt”, The TQM Magazine, Vol. 15 No. 6, pp. 381-390. DOI: http:// dx.doi.org/10.1108/09544780310502714

Murmura, F., Casolani, N., Liberatore, L., Vicentini, A. (2016), "An empirical analysis of ISO 9001: 2008 application in Italian services and manufacturing companies", Total Quality Management \& Business Excellence, pp. 1-12. DOI: http://dx.doi.org/10.10 80/14783363.2016.1237286

Okay, S., Semiz, S. (2013), “The effects of ISO 9000 quality management system implementation in small and medium-sized textile enterprises: Turkey experience", African Journal of Business Management, Vol. 7 No. 42, pp. 4311-4313.

Quazi, H. A., Padibjo, S. R. (1998) "A journey toward total quality management through ISO 9000 certification-a study on small-and medium-sized enterprises in Singapore" International Journal of Quality \& Reliability Management, Vol. 1 No. 5, pp. 489-508. DOI: http://dx.doi.org/10.1108/02656719810196225

Poksinska, B., Eklund, J. A., Jörn Dahlgaard, J. (2006), "ISO 9001: 2000 in small organisations: Lost opportunities, benefits and influencing factors", International Journal of Quality \& Reliability Management, Vol. 23 No. 5, pp. 490-512. DOI: http://dx.doi. org/10.1108/02656710610664578

Psomas, E. L., Fotopoulos, C. V., Kafetzopoulos, D. P. (2011), “Core process management practices, quality tools and quality improvement in ISO 9001 certified manufacturing companies", Business Process Management Journal, Vol. 17 No. 3, pp. 437-460. DOI: http://dx.doi.org/10.1108/14637151111136360

Santos, G., Barros, S., Mendes, F., Lopes, N. (2013), "The main benefits associated with health and safety management systems certification in Portuguese small and medium enterprises post quality management system certification", Safety science, Vol. 51 No. 1, pp. 29-36. DOI: http://dx.doi.org/10.1016/j.ssci.2012.06.014

Sousa-Poza, A., Altinkilinc, M., Searcy, C. (2009) "Implementing a functional ISO 9001 quality management system in small and medium-sized enterprises", International Journal of Engineering, Vol. 3 No. 3, pp. 220-228.

Wolniak, R. (2014), "Korzyści doskonalenia systemów zarządzania jakością opartych o wymagania normy ISO 9001: 2008”, Problemy jakości, Vol. 46 No. 3, pp. 20-25.

Zimon, D. (2015), "Impact of the implementation of quality management system on operating cost for small and medium-sized business organizations affiliated to a purchasing group", International Journal for Quality Research, Vol. 9 No. 4, pp. 551-564.

Zimon, D. (2016), "Influence of Quality Management System on Improving Processes in Small and Medium-Sized Organizations", QUALITY-Access to Succes, Vol. 17 No. 150 , pp. 61-63.

Zimon, D., Gazda, A. (2015), "Powiązania z dostawcami-integracja i partnerstwo", Problemy Jakości, No. 2, pp. 15-19.
ANALYSIS

OF THE IMPACT

OF STANDARDIZED

Dominik Zimon 